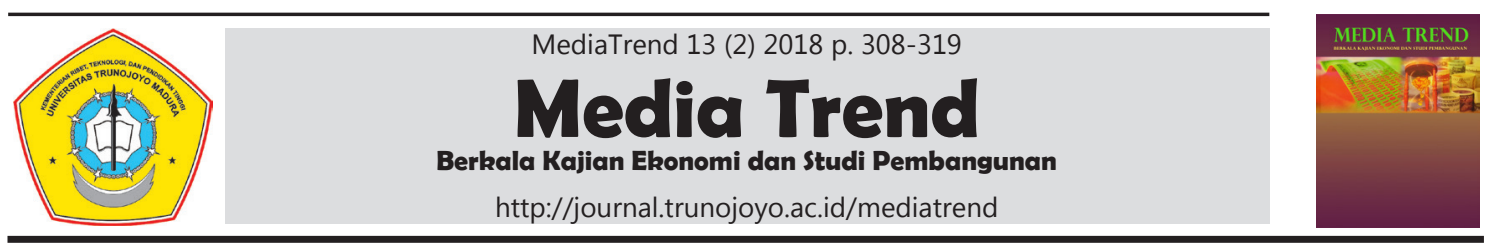

\title{
Daya Saing Komoditas Tembakau Indonesia dan Implikasinya Terhadap Produksi Dalam Negeri
}

\author{
Mohtar Rasyid $^{1^{*}}$, Henny Oktavianti ${ }^{2}$, Anita Kristina ${ }^{3}$ \\ 1,2,3 Jurusan Ekonomi Pembangunan Universitas Trunojoyo Madura
}

\section{Informasi Artikel \\ Sejarah artikel: \\ Diterima Oktober 2018 \\ Disetujui Oktober 2018 \\ Dipublikasikan Oktober 2018}

\section{Keywords:}

Competitiveness,

Tobacco,

Production,

Trade,

Prevalence

\begin{abstract}
A BS TRACT
Tobacco is one of Indonesia's unique agricultural commodities. During the slowdown global market for tobacco products, Indonesia still has a relatively important position. This considerable potential is relatively difficult to maintain because both internally and externally, the commodity of tobacco which is the main ingredient of cigarettes, faces very fierce obstacles. This study aims to analyze the competitiveness of tobacco commodities in Indonesia during the period 1970-2016. The competitiveness indicator used is the trade balance index. The method used is quantitative descriptive and regression methods to evaluate the association between competitiveness indicators and their main determinants: production. The results showed that at the beginning of the period of development, tobacco products had good competitiveness. However, entering the 1990s the position of the tobacco trade was reversed. On the other hand, demand for tobacco consumption and the prevalence of smoking in Indonesia are always increasing. As a result, the tendency to weaken competitiveness shown by import penetration will continue. The implication is that the government must stem tobacco imports to achieve two goals at once: improve the tobacco trade balance and hold the smoking prevalence rate that tends to increase.
\end{abstract}




\section{Pendahuluan}

Indonesia pada dasarnya memiliki potensi yang cukup besar dalam perdagangan tembakau dunia (Rasyid, 2017). Meskipun bukan menjadi pemain utama, peran Indonesia dalam perdagangan dunia tembakau hingga saat ini masih termasuk dalam sepuluh besar eksportir terbesar dunia. Potensi dari sisi produksi ini didukung oleh tingginya permintaan dalam negeri, terutama dalam bentuk konsumsi rokok. Di samping itu, Indonesia diuntungkan dengan sumber daya alam yang mendukung tumbuh berkembangnya pertanian tembakau di negeri ini.

Perkembangan tembakau sebagai produk perdagangan mendapat hambatan yang tidak ringan (Mathur \& Prabhakaran, 2012). Sebagai bahan baku utama rokok, tembakau juga terimbas oleh adanya isu mengenai masalah kesehatan. Meskipun penggunaan tembakau tidak hanya melulu untuk rokok, namun penggunaan untuk hal lain, relatif minim (Kulbicki \& Leslie, 2015). Sehingga masalah tembakau sering identik dengan produk rokok. Pada saat kampanye anti rokok ramai digalakkan, maka produksi tembakau juga akan terpengaruh (Joachim \& Jörg, 2014).

Kecenderungan global yang semakin menentang penggunaan rokok (Liu, Zhang, \& Wang, 2010), terbukti juga melemahkan hasil produksi tembakau. Akibatnya margin keuntungan dari usaha tani tembakau semakin menipis. Lebih jauh, volume perdagangan tembakau cenderung berkurang dari masa ke masa (Holden, 2017).

Meskipun mengalami penurunan volume secara gradual (Hilda \& Thomas, 2014), perdagangan tembakau tetap menjadi salah satu produk dagang yang menggiurkan. Tidak heran, banyak negara maju yang masih menempatkan produk tembakau sebagai produk dagang utama.

Posisi ini seharusnya dapat dimanfaatkan oleh Indonesia yang sedang membangun (Chasanah, Mulyo, \& Darwanto,
2017). Dengan potensi pasar yang relatif luas serta kepemilikan lahan pertanian subur yang cocok untuk tembakau, sudah sepantasnya Indonesia menjadi salah satu pemain kunci dalam perdagangan tembakau. Akan tetapi, fakta menunjukkan bahwa posisi perdagangan tembakau Indonesia tidak selalu dalam posisi yang menguntungkan (Luk Joossens \& Raw, 2012). Kapasitas produksi yang optimal mengakibatkan ekspor tembakau Indonesia cukup besar. Namun demikian, kebutuhan impor juga tidak kalah besarnya. Sebagai akibatnya, posisi perdagangan internasional Indonesia untuk produk tembakau mengalami defisit.

Sebagai produk yang tergolong dalam kategori sin commodity bersama minuman mengandung metil alcohol (Mododie, et al., 2013), produk tembakau kerap menemui beberapa resistensi yang cukup kuat. Berbagai macam keluhan penyakit kerap diasosisikan dengan produk ini (Nirwane \& Majumdar, 2016). Meskipun demikian, hasil produk tembakau dalam bentuk penerimaan cukai sebenarnya relatif menjanjikan. Hal ini juga yang dapat memicu adanya penyelundupan rokok disamping perdagangan gelap (Rajeev, 2012). Oleh sebab itu masingmasing negara menerapkan regulasi yang sangat ketat terhadap produk tembakau (Robertson, Louise, Hoek, McGee, \& Egan, 2015).

Sebagai sebuah produk pertanian, riset tentang tembakau relatif luas. Sebagaimana halnya produk pertanian lainnya yang menarik untuk dikaji dari sisi daya saing (Suhardedi, Darwanto, \& Irham, 2017), produk ini juga bisa dianalisis dari sudut pandang persaingan dagang dengan pihak luar negeri. Selain itu, produk rokok dapat dikaji dalam framework hubungan sebab akibat antara perdagangan luar negeri (ekspor) dengan produksi dalam negeri atau dosemstik (Tekin, 2012).

Disamping itu pula kajian mengenai rokok juga menarik tidak hanya dari sisi eko- 
nomi semata, namun dari segi upaya yang dilakukan oleh pihak yang bekerja keras untuk membendung pertumbuhan industri rokok (Thusingham, Ardura, Eerkens, Palazoglu, Shahbaz, \& Fiehn, 2013). Beberapa literatur bahkan secara khusus mengaitkan antara kebiasaan merokok dengan tingkat kesejahteraan atau masalah kemiskinan (Vincenzo \& Andrew, 2016). Lebih lanjut penelitian sebelumnya mengenai rokok juga mengaitkannya dengan pembangunan daerah (Yang, Tingzhong, Barnett, Rockett, \& Xiaozhao, 2015).

Berdasarkan penelusuran kajian sebelumnya, masih relatif sedikit kajian empiris yang mengaitkan hubungan langsung antara daya saing perdagangan dengan produksi tembakau secara khusus. Padahal, potensi perdagangan tembakau sebenarnya masih cukup besar dan memiliki hubungan kuat dengan persoalan yang ada di dalam negeri (domestik). Ketidakcermatan dalam mengamati arah angin perdagangan dunia pada akhirnya membawa masalah tersendiri bagi Indonesia. Dengan kekayaan alam serta potensi permintaan yang masih luas, pasar tembakau Indonesia perlahan namun pasti sudah dikuasai oleh pihak luar negeri (impor). Oleh karena itu diperlukan kajian yang lebih komprehensif.

Tujuan penelitian ini adalah (1) untuk mengetahui daya saing perdagangan komoditas produk tembakau Indonesia dalam jangka panjang, dan (2) untuk mengetahui dampak daya saing tersebut terhadap produksi tembakau di Indonesia.

\section{Metodologi Penelitian}

Penelitian ini menggunakan data Statistik Perkebunan Indonesia yang diterbitkan oleh Kementerian Pertanian RI tahun 2017 (Kementrian Pertanian RI, 2017) serta Buku Fakta Tembakau yang diterbitkan oleh Kementerian Kesehatan RI yang bekerja sama dengan Tobacco Control and Support Center pada tahun 2014 (Ke- mentrian Kesehatan RI dan TCSC, 2014). Data perdagangan juga diperoleh melalui sumber daring publikasi UN-COMTRADE serta sumber lain yang relevan. Data yang digunakan untuk menganalisis daya saing adalah data ekspor dan impor tembakau Indonesia periode tahun 1970-2016.

Daya saing komoditas tembakau dalam perdagangan internasional menggunakan indikator indeks keseimbangan perdagangan (Trade Balance Index, TBI) yang diformulasikan sebagai berikut (Taufiqurrahman \& Widodo, 2011):

$$
T B I_{i}=\frac{\left(X_{i}-M_{i}\right)}{\left(X_{i}+M_{i}\right)}
$$

dalam hal ini TBI adalah Trade Balance Index, $X$ adalah Volume Ekspor Tembakau, $M$ adalah Volume Impor Tembakau, $i$ adalah indikator waktu.

Indeks keseimbangan perdagangan memiliki interval nilai antara +1 sampai dengan -1 . Semakin mendekati +1 maka dapat dikatakan semakin memiliki daya saing. Sebaliknya, semakin mendekati -1 dikatakan semakin tidak memiliki daya saing.

Selanjutnya, untuk mengevaluasi implikasi daya saing terhadap produksi tembakau dalam negeri, digunakan metode analisis regresi. Guna menampung dinamika perubahan peta perdagangan tembakau dunia, maka sub-sampel penelitian dibagi menjadi dua periode: jangka panjang dan jangka pendek. Periode jangka panjang terdiri dari tahun 1970-2016. Sementara periode jangka pendek memotong periode penelitian dari tahun 1990 2011.

Model umum regresi yang digunakan adalah sebagai berikut:

$$
y_{i}=\alpha+\beta_{1} x_{1 i}+\cdots+\beta_{n} x_{n i}+\varepsilon
$$

dalam hal ini $y_{i}$ adalah produksi tembakau, $x_{i}$ adalah indikator daya saing seperti 
ekspor, a adalah variabel kontrol lainnya, $\varepsilon_{i}$ adalah error term.

Isu utama dalam analisis regresi jangka panjang dengan series yang cukup lama adalah isu stasioneritas dan keeratan hubungan jangka panjang atau kointegrasi. Untuk itu model regresi yang digunakan terdiri dari berbagai alternatif pemodelan seperti model kausalitas Granger dan model koreksi kesalahan (atau lebih dikenal sebagai Error Correction Model, ECM).

Model analisis kausalitas digunakan untuk menguji kemungkinan hubungan sebab akibat antar dua atau lebih variabel. Dalam penelitian ini, dua variabel utama yang dianalisis adalah produksi dan ekspor. Secara teori hubungan antar dua variabel ini bisa terjadi secara satu arah atau bisa juga timbal balik (dua arah). Evaluasi hubungan antar variabel dilakukan dengan menguji signifikansi koefisien regresi masing-masing persamaan yang memuat hubungan satu variabel dengan variabel lain yang dinyatakan dalam waktu lampau (lag). Sebuah variabel bisa jadi menjadi penyebab dari variabel lainnya, jika nilai masa lalunya signifikan terhadap variabel lain dimaksud.

Selanjutnya model koreksi kesalahan digunakan untuk mengevaluasi kaitan antar variabel yang memiliki karakter tidak stasioner. Oleh karena itu, sebelum dilakukan estimasi regresi perlu dicek masalah stasioneritas variabel. Pengujian stasioneritas dapat dilakukan dengan menggunakan pendekatan Augmented Dickey Fuller (ADF). Apabila semua variabel yang dianalisis sudah stasioner dalam tingkat level, maka bisa dilakukan regresi untuk memperoleh estimasi model jangka panjangnya. Namun apabila level stasioneritas variabel penelitian berbeda, maka perlu diuji terlebih dahulu tingkat stasioneritasnya. Dalam sebagian besar kasus, variabel dalam bentuk fist difference sudah stasioner.
Selanjutnya perlu dibuat model koreksi kesalahan (Model ECM) untuk menangkap penyesuaian yang dilakukan oleh satu variabel untuk merespon perubahan dari variabel lain. Model ECM yang baik dapat mencerminkan adanya hubungan integrasi antar variabel.

Setelah mengevaluasi hubungan antara produksi dengan ekspor dalam jangka panjang, penelitian ini juga menguji hubungan antar indikator daya saing ekspor dengan produksi menggunakan variabel yang lebih banyak. Tujuan variabel yang lebih banyak ini tidak lain adalah untuk menangkap atau mengisolasi faktor lain penentu produksi disamping variabel daya saing sebagai variable of interest.

Periode data yang digunakan lebih pendek, namun detail informasinya lebih banyak karena variabel kontrol yang digunakan juga lebih banyak. Isu utama dari pendekatan ini adalah masalah multikolinearitas antar variabel bebas, spesifikasi model dan heteroskedastisitas. Untuk mengatasi masalah tersebut, penelitian ini menggunakan berbagai bentuk spesifikasi model yang berbeda-beda. Khusus untuk mengatasi masalah heteroskedastisitas, dalam penelitian ini memanfaatkan penggunaan standard error estimasi yang robust.

\section{Hasil dan Pembahasan}

Selama periode 1970-2016 terjadi perkembangan yang cukup dinamis dalam perdagangan tembakau. Pada awal 1970 sampai dengan awal 1990an, volume ekspor tembakau masih lebih tinggi dibandingkan dengan volume impor. Meskipun ekspor lebih tinggi, akan tetapi secara bertahap porsi ekspor relatif mulai menurun.

Selanjutnya pada periode 19902010 eskpor dan impor tembakau mulai berimbang. Hal yang perlu dicatat adalah bahwa sejak tahun 2006 hingga tahun 


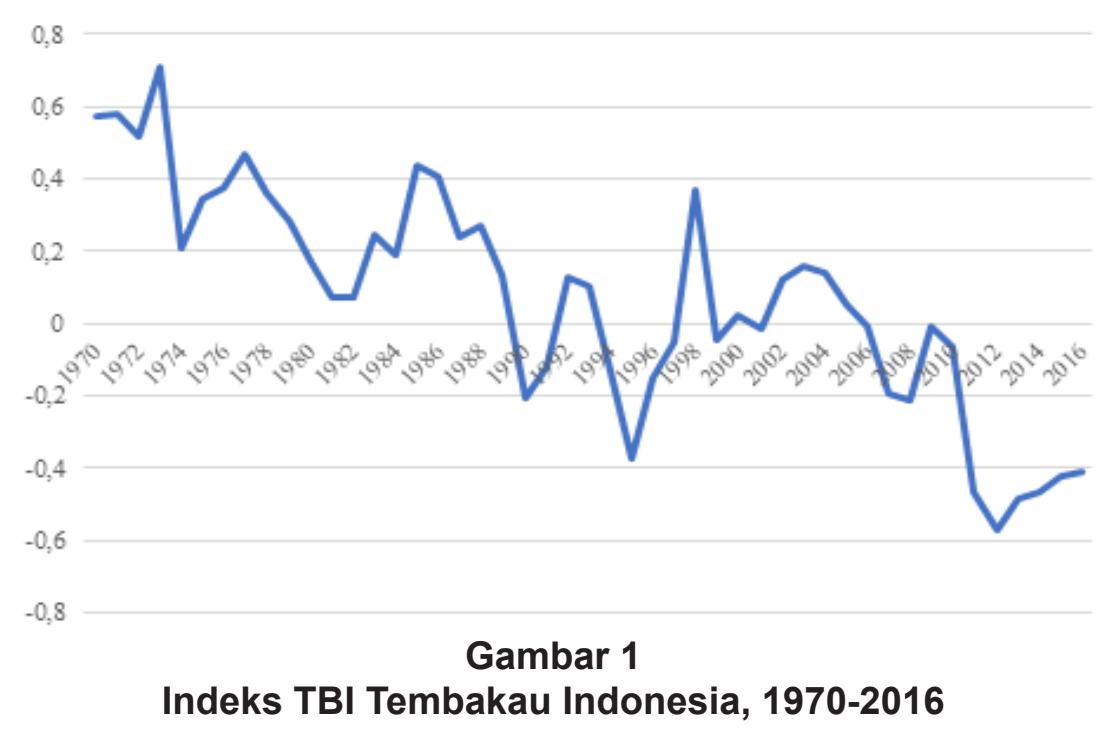

2017, Indonesia secara konsisten telah menjadi net importir tembakau. Potret daya saing komoditas tembakau ini secara lebih terinci dapat diperhatikan dalam ilustrasi gambar 1.

Gambar 1 diatas menunjukkan perubahan Trade Balance Index (TBI) untuk komoditas tembakau Indonesia. Apabila ditarik garis trend linear dari tahun 1970 hingga tahun 2016 maka akan nampak bahwa garis trend tersebut akan memiliki kemiringan negatif. Ini menggmbarkan bahwa TBI mengalami penurunan. Dengan kata lain daya saing perdagangan komoditi tembakau Indonesia semakin lama semakin melemah. Penetrasi impor telah menutup hasil ekspor yang yang selama ini telah diperoleh.
Kondisi daya saing yang semakin melemah ini ditenggarai akan memiliki dampak yang serius terhadap kinerja pertanian tembakau secara keseluruhan, termasuk produksi tembakau. Untuk mengevaluasi keterkaitan daya saing perdagangan dengan produksi, maka akan diuji hubungan kausalitas antara tingkat produksi dengan tingkat ekspor.

Hasil estimasi model kausalitas Granger untuk variabel produksi versus tingkat ekspor dapat diperhatikan dalam tabel 1 yang menyajikan ringkasan printout olah data kausalitas antara ekspor dengan produksi tembakau. Panel atas menyajikan hasil olah data dengan menggunakan data lag 2 periode (dua tahun). Sementara panel bawah menyajikan ha-

Tabel 1

Kausalitas Ekspor VS Produksi

\begin{tabular}{lcc}
\hline \multicolumn{3}{c}{ lag 2 tahun } \\
Hipotesis nol & F-stat & Prob. \\
Produksi $\rightarrow$ Ekspor & 7,59 & 0,0018 \\
Ekspor $\rightarrow$ Produksi & 7,06 & 0,0026 \\
\hline \multicolumn{3}{c}{ lag 4 tahun } \\
\hline Hipotesis nol & F-stat & Prob. \\
Produksi $\rightarrow$ Ekspor & 2,89 & 0,0392 \\
Ekspor $\rightarrow$ Produksi & 2,86 & 0,0406 \\
\hline
\end{tabular}

Sumber: olah data sekunder (2018) 
sil olah data lag 4 tahun. Hipotesis yang ditunjukkan oleh anak panah menyatakan bahwa variabel yang sebelah kiri tidak menyebabkan variabel yang sebelah kanan.

Hasil perhitungan menunjukkan bahwa tidak ada satupun hipotesis nol yang diterima. Ini menunjukkan bahwa terdapat hubungan bolak balik antara ekspor dengan produksi. Tingkat ptoduksi mempengaruhi ekspor, demikian sebaliknya ekspor mempengaruhi produksi. Hubungan timbal balik ini menegaskan keeratan antara tingkat produksi dengan ekspor. Indikasi awal ini menunjukkan bahwa terdapat implikasi pergadangan (lebih tepatnya ekspor) terhadap produksi tembakau.
Untuk menguji lebih dalam mengenai hubungan antara ekspor dengan produksi, maka dilakukan uji regresi produksi dengan ekspor, ditambah dengan variabel lahan sebagai kontrol. Hasil ujinya dapat diperhatikan pada tabel 2 menyajikan estimasi model jangka panjang produksi dengan ekspor dan lahan. Hasil estimasi menunjukkan bahwa luas lahan tanam dan ekspor memiliki pengaruh yang sangat signifikan terhadap besarnya produksi. Sebelum menganalisis lebih jauh, hasil estimasi ini dapat sahih digunakan jika semua variabel yang terlibat telah memenuhi syarat stasioneritas.

Tabel 2

Regresi Produksi Jangka Panjang

\begin{tabular}{lrrc}
\hline \multicolumn{4}{c}{ Dependent: Produksi } \\
\hline Variabel & \multicolumn{1}{c}{ Koefisien } & t-stat & Prob. \\
\hline Lahan & 0,940 & 7,138 & 0,00 \\
Ekspor & 1,563 & 4,558 & 0,00 \\
Constant & $-100755,2$ & $-3,435$ & 0,00 \\
\hline R-square & 0,657 & & \\
F-Stat & 37,362 & & \\
Prob. F & 0,000 & & \\
\hline
\end{tabular}

Sumber: olah data sekunder (2018)

Tabel 3

Uji Stasioneritas: ADF

\begin{tabular}{|c|c|c|}
\hline \multicolumn{3}{|c|}{ Level } \\
\hline Variabel & t-stat & Prob. \\
\hline Produksi & $-3,082$ & 0,035 \\
\hline Lahan & $-5,544$ & 0,000 \\
\hline Ekspor & $-1,752$ & 0,398 \\
\hline \multicolumn{3}{|c|}{ First Difference } \\
\hline Variabel & F-stat & Prob. \\
\hline Produksi & $-8,433$ & 0,000 \\
\hline Lahan & $-9,760$ & 0,000 \\
\hline Ekspor & $-6,077$ & 0,000 \\
\hline
\end{tabular}

Sumber: olah data sekunder (2018) 
Apabila salah satu atau beberapa variabel tidak stasioner pada level, maka perlu dilakukan treatment lanjutan. Dalam penelitian ini variabel Produksi, Lahan dan Ekspor diuji tingkat stasioneritasnya menggunakan statistik Augmented Dickey Fuller (ADF).

Risalah uji ADF untuk ketiga variabel penelitian dapat dirangkum dalam tabel 3 dengan hasil pengujian stasioneritas menunjukkan bahwa Variabel Produksi dan Lahan sudah stasioner dalam level. Akan tetapi Variabel Ekspor tidak stasioner dalam level. Pengujian dilanjutkan dengan melanjutkan uji stasioner setelah semua variebel diambil nilai perbedaannya dengan masa lampau (First Difference). Hasil perhitungannya dapat dilihat dalam Tabel 3 panel bawah.

Pada tingkat first-difference, semua variabel sudah stasioner. Meskipun telah sama-sama stasioner namun bukan berarti bahwa hubungan antar variabel sudah dapat terkonfirmasi. Untuk itu perlu dilakukan uji kointegrasi guna memastikan adanya kaitan jangka panjang antar variabel penelitian.

Salah satu cara untuk mengevaluasi hubungan antar variabel yang tidak stasioner dalam level, namun stasioenr dalam fist-difference adalah menggunakan mekanisme model koreksi kesalahan, atau lebih dikenal sebagai ECM.

Tabel 4 diatas menyajikan hasil olah data model ECM. Koefisien kritis yang pertama harus diperiksa adalah signifikansi negatif dari residual lag pertama yang diperoleh sebelumnya dari regresi jangka panjang (perhatikan hasil regresi pada Tabel 2). Pengujian menunjukkan bahwa residual dimaksud (Ut-1) nilainya sangat signifikan dan negatif.

Hasil estimasi model ECM dapat juga dikatakan sebagai regresi jangka pendek. Berdasarkan hasil estimasi dapat diketahui bahwa perilaku ekspor terhadap produksi berbeda untuk kasus jangka Panjang dengan kasus jangka pendek. Dalam jangka pendek, ekspor memiliki pengaruh negatif terhadap produksi. Seiring dengan berjalannya waktu, hubungan antara ekspor dengan produksi menjadi positif signifikan.

Selanjutnya untuk mengevaluasi dampak langsung daya saing terhadap produksi, penelitian ini juga menggunakan data dengan periode yang lebih pendek yakni antara tahun 1990-2011. Selama periode tersebut daya saing perdagangan tembakau mengalami pasang surut sebelum akhirnya secara konsisten terus menerus mengalami penurunan.

Untuk mengantisipasi masalah bias akibat pengabaian variabel yang relevan, penelitian ini menggunakan beberapa variabel penjelas tambahan. Sedangkan untuk mengantisipasi masalah spesifikasi pemodelan, penelitian ini melakukan serangkaian estimasi dengan model spesifikasi yang bervariasi.

Tabel 4

Regresi Produksi Jangka Pendek

\begin{tabular}{lrrr}
\hline \multicolumn{4}{c}{ Dependent: $\Delta$ (Produksi) } \\
\hline Variabel & Koefisien & t-stat & Prob. \\
\hline Constant & 1608,237 & 0,518 & 0,607 \\
$\Delta$ (Lahan) & 0,738 & 9,164 & 0,000 \\
$\Delta$ (Ekspor) & $-1,016$ & $-1,892$ & 0,066 \\
Ut-1 & $-0,458$ & $-3,296$ & 0,002 \\
\hline R-square & 0,759 & & \\
F-Stat & 38,998 & & \\
Prob. F & 0,000 & & \\
\hline
\end{tabular}

Sumber: olah data sekunder (2018) 
Tabel 5

Regresi Dampak Daya Saing Perdagangan Terhadap Produksi

\begin{tabular}{|c|c|c|c|c|}
\hline Variables & Produksi & Produksi & Logproduksi & Produksi \\
\hline Lahan & $\begin{array}{c}0.106 \\
(0.0636)\end{array}$ & - & - & $\begin{array}{c}0.382^{\star * *} \\
(0.106)\end{array}$ \\
\hline Petani & $\begin{array}{c}-0.0656^{\star *} \\
(0.0301)\end{array}$ & - & - & $\begin{array}{l}0.198^{\star \star *} \\
(0.0513)\end{array}$ \\
\hline Konsumsi & $\begin{array}{l}1.021^{\star \ldots \pi} \\
(0.0790)\end{array}$ & - & - & - \\
\hline TBI & $\begin{array}{c}-95,528^{* x *} \\
(14,254)\end{array}$ & $\begin{array}{c}-91,630^{* x *} \\
(14,460)\end{array}$ & $\begin{array}{l}-0.616^{\text {} \pm \star} \\
(0.0511)\end{array}$ & - \\
\hline Time & $\begin{array}{l}629.1^{ \pm \star} \\
(269.2)\end{array}$ & $\begin{array}{l}520.1^{*} \\
(286.4)\end{array}$ & $\begin{array}{c}0.00357^{* x+} \\
(0.00113)\end{array}$ & - \\
\hline Loglahan & - & $\begin{array}{l}30,941^{* *} \\
(10,886)\end{array}$ & $\begin{array}{c}0.119^{\star \star} \\
(0.0471)\end{array}$ & - \\
\hline Logpetani & - & $\begin{array}{l}-35,593^{*} \\
(17,158)\end{array}$ & $\begin{array}{l}-0.140^{\star *} \\
(0.0638)\end{array}$ & - \\
\hline Logkonsumsi & - & $\begin{array}{c}159,236^{* * \star} \\
(11,431)\end{array}$ & $\begin{array}{l}1.002^{* * *} \\
(0.0479)\end{array}$ & - \\
\hline Constant & $\begin{array}{c}3,993 \\
(7,923)\end{array}$ & $\begin{array}{c}-1.659 \mathrm{e}+06^{* \star *} \\
(117,598)\end{array}$ & $\begin{array}{c}0.333 \\
(0.510)\end{array}$ & $\begin{array}{l}-27,529 \\
(21,820)\end{array}$ \\
\hline $\begin{array}{l}\text { Observations } \\
\text { R-squared }\end{array}$ & $\begin{array}{c}22 \\
0.974\end{array}$ & $\begin{array}{c}22 \\
0.969\end{array}$ & $\begin{array}{c}22 \\
0.989\end{array}$ & $\begin{array}{c}22 \\
0.650\end{array}$ \\
\hline
\end{tabular}

Sumber: olah data sekunder (2018)

Tabel 5 menyajikan hasil estimasi regresi dampak daya saing perdagangan tembakau terhadap produksi tembakau dalam negeri. Variabel dependent yang digunakan dalam estimasi tersebut adalah produksi tembakau yang dinyatakan dalam bentuk level maupun dalam bentuk logaritma natural. Model regresi dasar yang digunakan adalah model produksi sederhana dengan dua variabel penjelas; yakni luas lahan dan jumlah petani (perhatikan kolom 4 dalam Tabel 5). Sebagai produk pertanian, produksi tembakau sangat ditentukan oleh luas lahan pertanian dan juga jumlah petani. Kedua variasi variabel tersebut menyumbang sekitar 65 persen terhadap variasi produksi. Tentu saja beberapa variabel penting, seperti curah hujan, pemupukan serta bibit juga berpengaruh. Variabel lain tersebut dalam model alternatif diwakili oleh indikator waktu dan selebihnya masuk sebagai error term.
Variabel utama dalam Tabel 5 adalah Variabel TBI yang merupakan indikator daya saing. Dampak daya saing perdagangan terhadap produksi tembakau dapat diperhatikan dari koefisien regresi baris keempat. Sedangkan variabel penjelas lainnya dijadikan sebagai variabel kontrol.

Masing-masing kolom yang terdapat dalam Tabel 5 menggunakan spesifikasi yang berbeda. Kolom 1 menggunakan model linear biasa, kolom 2 menggunakan model semi log dan kolom 3 menggunakan model double-log. Kolom 4 merupakan model dasar.

Hasil estimasi menunjukkan bahwa produksi tembakau pada dasarnya sangat tergantung dengan luas lahan. Banyaknya petani tidak menjadi faktor utama. Besarnya konsumsi juga sangat berpengaruh signifikan terhadap produksi. Faktor lain, yang diasumsikan berubah secara linear diwakili oleh variabel time. 
Setelah semua variabel penting dimasukkan dalam model, maka analisis selanjutnya difokuskan pada pengaruh daya saing yang ditunjukkan oleh indikator TBI terhadap produksi. Dari semua alternatif model yang digunakan, hasil estimasi yang diperoleh relatif konsisten. Daya saing memiliki hubungan negatif dengan produksi. Dengan kata lain promosi ekspor justru akan membatasi produksi dalam negeri. Hasil ini konsisten dengan estimasi model di Tabel 4 yang menemukan hubungan negatif ekspor dengan produksi dalam jangka pendek.

Mengapa daya saing ekspor justru berdampak negatif terhadap produksi? Terdapat beberapa penjelasan alternatif berkaitan dengan masalah ini. Pertama, daya saing ekspor tembakau selama periode penelitian mengalami pelemahan. Akibatnya hasil produksi hanya dapat digunakan untuk kebutuhan domestik dengan nilai tambah yang relatif kecil. Di lain pihak, faktor penentu produksi seperti lahan dan petani tembakau relatif konstan. Sebagai implikasinya, produksi juga mengalami stagnasi.
Arah hubungan antara produksi dengan ekspor bisa jadi berbalik. Produksi yang stagnan menyebabkan rendahnya kemampuan ekspor, sehingga permintaan pasar domestik harus ditutup dengan impor yang semakin banyak.

Gambar 2 dibawah menunjukkan perilaku ekspor-impor tembakau serta produksi tembakau di Indonesia pada tahun 1975-2016. Panel atas menggambarkan produksi, sedangkan dua grafik dibawahnya menunjukkan ekspor dan impor. Data impor dinyatakan dalam grafik garis yang terputus-putus.

Hasil pengamatan menunjukkan bahwa trend produksi diikuti oleh perkembangan ekspor yang melambat. Sebaiknya impor mengalami peningkatan yang luar biasa pada akhir-akhir periode pengamatan.

Kelebihan impor atas ekspor menunjukkan melemahnya daya saing perdagangan. Fenomena impor lebih besar daripada ekspor sudah dapat dirasakan sejak tahun 2000-an.

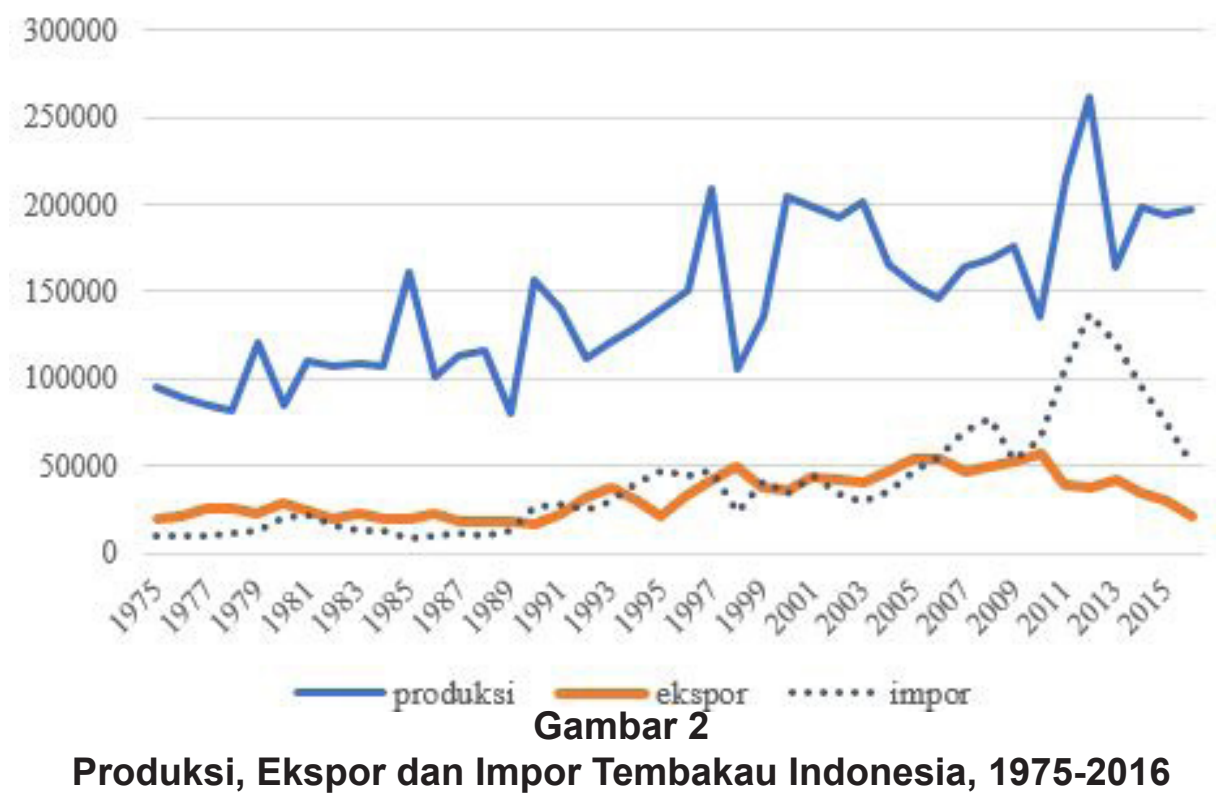


Sebagai produk yang sangat tergantung dengan curah hujan, tidak mengherankan jika produksi tembakau mengalami fluktuasi jangka pendek. Ter dapat kecenderungan bahwa produksi dapat ditingkatkan namun dengan marjinal produk yang relatif sedikit. Di sisi lain, ekspor bergerak perlahan mengikuti tren produksi namun dengan kecepatan yang sangat lambat.

Mengapa impor begitu melesat dengan cepat? Jawabannya adalah untuk memenuhi permintaan dalam negeri yang terus meningkat. Indonesia dikenal sebagai negara dengan tingkat prevalensi merokok yang cukup besar.

Guna memenuhi kebutuhan konsumsi domestik itulah, maka ekspor tertahan sehingga daya saing perdagangan tidak dapat diperbaiki secara signifikan. Sebagai gambaran, lebih dari separuh jumlah penduduk Indonesia laki-laki dewasa tercatat sebagai perokok aktif.

Gambar 3 diatas menunjukkan tingkat prevalensi merokok usia dewasa di Indonesia tahun 1995-2013. Untuk individu laki-laki terjadi peningkatan dari 53,4 persen pada tahu 1995 menjadi 66 persen pada tahun 2013. Grafik yang lebih kecil menunjukkan tingkat prevalensi merokok wanita dewasa.
Apabila ditinjau dari kenaikan per periode, seolah tampak terdapat kenaikan prevalensi yang sangat kecil. Namun jika angka tersebut dikalikan dengan jumlah penduduk maka akan cukup fantastis.

Besarnya konsumsi dalam negeri berimbas pada kebutuhan impor yang cukup banyak. Jika impor ini ditahan maka harga rokok dalam negeri akan meningkat sehingga diharapkan akan mampu menekan prevalensi merokok.

Kebutuhan konsumsi yang cukup besar seharusnya dapat dipenuhi oleh produksi dalam negeri guna menghemat pengeluaran devisa. Untuk itu impor perlu ditahan dan daya saing perdagangan tembakau akan meningkat dengan sendirinya.

\section{Kesimpulan dan Saran}

Hasil penelitian dengan jelas menunjukkan bahwa daya saing perdagangan produk tembakau mengalami penurunan. Terbatasnya lahan tembakau, jumlah petani yang relatif sedikit serta pengaruh cuaca turut menyumbang terhadap stagnasi produksi. Padahal terdapat kaitan jangka panjang antara ekspor tembakau dengan produksi dalam negeri.

Besarnya kebutuhan konsumsi tembakau tidak harus melulu diselesaikan dengan impor. Justru pembatasan impor

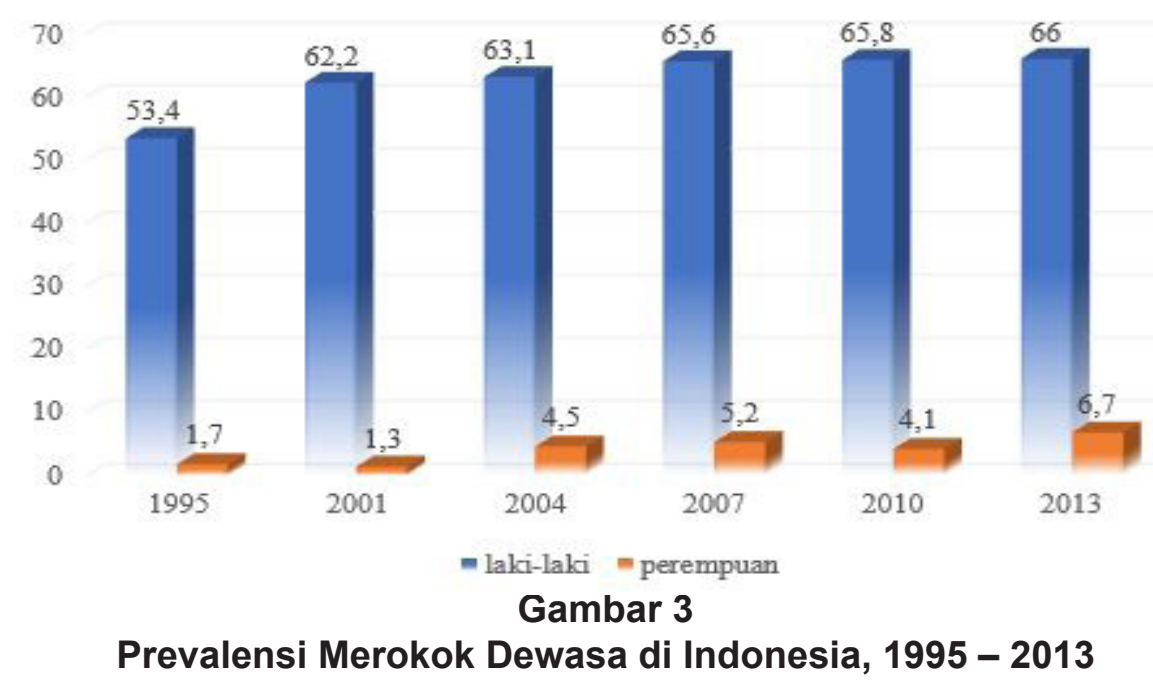


akan berdampak pada kenaikan harga produk tembakau dalam negeri (rokok). Kenaikan harga ini tentu akan menambah pundi penerimaan negara. Di sisi lain, angka prevalensi merokok Indonesia yang sangat tinggi akan dapat ditahan, karena rokok tidak lagi "murah". Perlu konsistensi pemerintah untuk menerapkan kebijakan untuk produk tembakau.

\section{Ucapan Terima Kasih}

Penulis mengucapkan terima kasih atas bantuan dana penelitian yang diperoleh dari Direktorat Riset dan Pengabdian Masyarakat (DRPM), Direktorat Jenderal Penguatan Riset dan Pengembangan, Kementerian Riset, Teknologi dan Pendidikan Tinggi (Kemenristekdikti), sesuai dengan kontrak penelitian Nomor 103/SP2H/LT/ DRPM/2018.

\section{Daftar Pustaka}

Chasanah, N., Mulyo, J. H., \& Darwanto, D. H. (2017). Competitiveness and Export Simiarity of Indonesia Holticulture in The ASEAN-ASEAN+3. Agro Ekonomi, 28(1), 32-47.

Hilda, M., \& Thomas, R. (2014). Delta and vega exposure trading in stock and option markets. Journal of Financial Markets, 18, 96-125.

Holden, C. (2017). Graduated sovereignty and global governance gaps: Special economic zones and the illicit trade in tobacco products. Political Geography, 59, 72-81.

Joachim, M., \& Jörg, S. (2014). The economic impact of Swiss smoking bans on the hospitality sector. Economics Letters, 124(1), 136-139.

Kementrian Kesehatan RI dan TCSC. (2014). Fakta Tembakau dan Permasalahannya di Indonesia. Jakarta: Tobacco Control and Support Center IAKMI.
Kementrian Pertanian RI. (2017). Statistik Perkebunan Indonesia 2015-2017: Tembakau. Jakarta: Direktorat Jenderal Perkebunan, Kementrian Pertanian RI.

Kulbicki, K. M., \& Leslie, T. F. (2015). The effect on spatial accessibility from removing tobacco from pharmacies in the Washington, DC area. Public Health, 129(9), 1285-1287.

Liu, F., Zhang, N. K.-W., \& Wang, H. (2010). Reduced smoking and rising obesity: Does smoking ban in the workplace matter? Economics Letters, 108(3), 249-252.

Luk Joossens, L., \& Raw, M. R. (2012). From cigarette smuggling to illicit tobacco trade. Tobacco Control, 230-234.

Mathur, M. R., \& Prabhakaran, D. (2012). Tobacco and CVD: A Historical Perspective. Global Heart, 107-111.

Mododie, R., Stuckler, D., Monteiro, C., Sheron, N., Neal, B., Thamarangsi, T., . . . Casswell, S. (2013). Profits and pandemics: prevention of harmful effects of tobacco, alcohol, and ultraprocessed food and drink industries. The Lancet, 381(9867), 670-679.

Nirwane, A., \& Majumdar, A. (2016). Resveratrol and pterostilbene ameliorate the metabolic derangements associated with smokeless tobacco in estrogen deficient female rats. Journal of Functional Foods, 23, 261-277.

Rajeev, K. G. (2012). Effect of generic cigarettes on US cigarette demand and smuggling. Economics Letters, 115(1), 114-117.

Rasyid, M. (2017). Impact of the Free Trade Zone on Cigarette Consumption: An Examination of Indonesian Households. Journal of Business and Economics Review, 2(4), 10-17.

Robertson, L., Louise, M., Hoek, J., McGee, 
R., \& Egan, R. (2015). Regulating the sale of tobacco in New Zealand: A qualitative analysis of retailers' views and implications for advocacy. International Journal of Drug Policy, 26(12), 1222-1230.

Suhardedi, C., Darwanto, D. H., \& Irham. (2017). Competitiveness Rice Farming in Sragen Regency. Agro Ekonomi, 28(1), 19-31.

Taufiqurrahman, E., \& Widodo, T. (2011). Modified LQ and Dinamic Economic Base. Fokus Ekonomi, 168-182.

Tekin, R. B. (2012). Economic growth, exports and foreign direct investment in Least Developed Countries: A panel Granger causality analysis. Economic Modelling, 29(3), 868-878.

Thusingham, S., Ardura, D., Eerkens, J. W., Palazoglu, M., Shahbaz, S., \& Fiehn, O. (2013). Hunter-gatherer tobacco smoking: earliest evidence from the Pacific Northwest Coast of North America. Journal of Archaeological Science, 40(2), 1397-1407.

Vincenzo, C., \& Andrew, M. J. (2016). Smoking for the poor and vaping for the rich? Distributional concerns for novel nicotine delivery systems. Economics Letters, 149, 71-74.

Yang, T., Tingzhong, Y., Barnett, R., Rockett, I. R., \& Xiaozhao, Y. (2015). The impact of regional economic reliance on the tobacco industry on current smoking in China. Health \& Place, 33, 159-171. 